\title{
PHEROMONAL FACILITATION OF OVULATION IN THE IMMATURE MOUSE
}

\author{
M. X. ZARROW, * S. A. ESTES, $\uparrow$ V. H. DENENBERG* \\ AND J. H. GLARK $\ddagger$ \\ $\$$ Departments of Biological Sciences and Psychology, Purdue University, \\ Lafayette, Indiana 47907, and *Department of Biobehavioral Sciences, \\ The University of Connecticut, Storrs, Connecticut 06268, U.S.A.
}

(Received 8th Fune 1970)

\begin{abstract}
Summary. Facilitation of PMSG- or HCG-induced ovulation occurs in the immature female mouse exposed to the presence of, but not in contact with, an adult male. The effect is not seen if an immature or castrated adult male is used. Removal of the olfactory bulbs in the female also prevents facilitation due to the presence of the male. It is suggested that a number of different effects seen in the female due to a pheromone released by the male may be mediated through a single environmental stimulus.
\end{abstract}

Pheromones from the male mouse are known to influence reproductive activities in both the adult and immature female mouse (Lee \& Boot, 1955; Whitten, 1956a; Bruce, 1959; Parkes \& Bruce, 1961; Eleftheriou, Bronson \& Zarrow, 1962; Vandenbergh, 1967). Whitten (1966) has suggested that the male pheromone stimulates FSH secretion. The present study reports a pheromonal facilitation of gonadotrophin-induced ovulation in the immature mouse and is interpreted as indicating the release of both gonadotrophins in the female by the action of a male pheromone.

Immature female mice of the Rockland Swiss strain were weaned at 20 days of age and housed six or less to a cage in a room which only contained similar animals. Food and water were supplied freely and a light-dark cycle of 13-11 $\mathrm{hr}$ was used with the lights turned on at 07.00 hours. At 09.00 hours, when they were 24 days old, the females received a subcutaneous injection of either 7 or 10 i.u. PMSG dissolved in $0.1 \mathrm{ml}$ of $0.85 \%$ saline. At $50 \mathrm{hr}$ after the PMSG injection, each of the experimental females was placed in a cage with, but separated by a double wire partition from, one mature male mouse. The male had previously been placed in the adjoining compartment for at least 1 day to permeate the area with his odour. When the female was introduced, the male was placed on the unsoiled side and the female was placed on the freshly soiled side. Control animals were not moved. All animals were killed 72 to $77 \mathrm{hr}$ after PMSG injection and ova were counted under a dissecting microscope (Rowlands, 1942; Zarrow,

$\dagger$ Present address: The University of Rochester, School of Medicine and Dentistry, Rochester, New York 14620. 
Galdwell, Hafez \& Pincus, 1958). Uterine weights were also obtained for a group of control and anosmic mice. Statistical analysis involved Fisher's exact probability test and the chi-square test with Yates' correction for evaluation of percentages, and the $t$ test for the mean number of eggs recovered. All probability values are based on two-tailed tests of significance.

Groups I to IV in Table 1 summarize the findings. Fifty-five per cent of the animals kept in the male-free environment and given 7 i.u. PMSG ovulated, whereas $81 \%$ of the animals exposed to the male ovulated $(P<0 \cdot 20)$. The mean number of eggs recovered was 6.8 for the control group and 12.5 for the mice

TABLE 1

FACILITATION OF PMSG-INDUCED OVULATION IN THE IMMATURE MOUSE ON EXPOSURE TO AN ADULT MALE

\begin{tabular}{|c|c|c|c|c|c|c|c|}
\hline Group & Treatment & $\mathcal{N}$ & $\begin{array}{c}\% \\
\text { Ovulating }\end{array}$ & $\begin{array}{l}\text { Mean no. of } \\
\text { ova recovered }\end{array}$ & $\begin{array}{c}\text { Group } \\
\text { comparison }\end{array}$ & 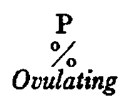 & $\begin{array}{c}\mathbf{P} \\
\text { Mean no. of } \\
\text { ova recovered }\end{array}$ \\
\hline I & $\begin{array}{l}7 \text { i.u. PMSG } \\
\text { Controls }\end{array}$ & 20 & 55 & $6 \cdot 8$ & & & \\
\hline II & $\begin{array}{l}7 \text { i.u. PMSG } \\
\text { Exposed to } \\
\text { adult male }\end{array}$ & 16 & 81 & $12 \cdot 5$ & I versus II & $0 \cdot 20$ & 0.05 \\
\hline III & $\begin{array}{l}10 \text { i.u. PMSG } \\
\text { Controls }\end{array}$ & 48 & 23 & $1 \cdot 6$ & & & \\
\hline IV & $\begin{array}{l}10 \text { i.u. PMSG } \\
\text { Exposed to } \\
\text { adult male }\end{array}$ & 35 & 52 & $9 \cdot 8$ & III versus IV & 0.02 & 0.001 \\
\hline V & $\begin{array}{l}10 \text { i.u. PMSG } \\
\text { Sham anosmic } \\
\text { exposed to } \\
\text { adult male }\end{array}$ & 15 & 53 & $10 \cdot 6$ & & & \\
\hline VI & $\begin{array}{l}10 \text { i.u. pMsG } \\
\text { Anosmic, } \\
\text { exposed to } \\
\text { adult male }\end{array}$ & 15 & 20 & $1 \cdot 8$ & $\mathrm{~V}$ versus $\mathrm{VI}$ & $0 \cdot 20$ & 0.05 \\
\hline
\end{tabular}

$\mathrm{N}=$ No. of female mice.

exposed to the male environment $(P<0 \cdot 05)$. The data obtained with 10 i.u. PMSG showed a drop in the percentage of animals ovulating and the mean egg recovery count when compared with the group treated with 7 i.u. PMSG. However, a significant increase in both the percentage of mice ovulating $(P<0.02)$ and the average number of ova released $(P<0.001)$ was noted following exposure to the male.

The decreased response to $10 \mathrm{i}$.u. as compared to $7 \mathrm{i}$.u. has been confirmed by us with other strains of mice. While we have no data on this discrepancy at the present time, we have suggested that the decreased response in the mouse with higher doses of PMSG may be due to preluteinization (Wilson \& Zarrow, 1962).

The effect of the male's presence on HCG-induced ovulation was investigated in a second experiment. Female mice, 24 days old, which had been in a malefree environment for 4 days, were separately exposed to a mature male for $55 \mathrm{hr}$. The exposure procedure was identical to the one previously described. Control 
animals were individually housed in cages in the male-free environment. At 16.00 hours, when they were 26 days old, all animals received 5 i.u. HCG in $0.1 \mathrm{ml}$ of $0.85 \%$ saline. Between 09.00 and 11.00 hours the following day, all animals were killed and examined for the presence of ova. These results are summarized in Table 2 . Only $25 \%$ of the control animals ovulated, whereas $89 \%$ of the animals that were exposed to males ovulated $(P<0.001)$. When females were exposed to a male castrated before puberty or to an immature male (less than 30 days old), $30 \%$ and $40 \%$ of the animals ovulated $(P<0.004$ and $<0.02$, respectively, when compared to the group exposed to an adult male). Thus, a mature testis appears to be necessary for the male to affect a significant facilitation of ovulation in the HGG-treated immature female.

TABLE 2

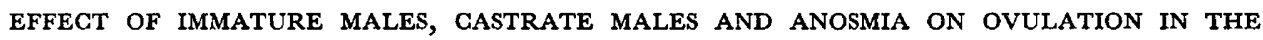
MOUSE INDUCED BY 5 I.U. OF HCG

\begin{tabular}{|c|c|c|c|c|c|c|c|}
\hline Group & Treatment & $\mathcal{N}$ & Ovulating & $\begin{array}{l}\text { Mean no. of } \\
\text { ova recovered }\end{array}$ & $\begin{array}{c}\text { Group } \\
\text { comparison }\end{array}$ & $\stackrel{\mathrm{P}}{\%} \underset{\text { Ovulating }}{\%}$ & $\begin{array}{c}\mathrm{P} \\
\text { Mean no. of } \\
\text { ova recovered }\end{array}$ \\
\hline I & Controls & 16 & 25 & $2 \cdot 3$ & I versus II & & \\
\hline II & $\begin{array}{l}\text { Exposed to } \\
\text { adult male }\end{array}$ & 19 & 89 & $12 \cdot 5$ & & 0.001 & 0.001 \\
\hline III & $\begin{array}{l}\text { Exposed to } \\
\text { castrated adult } \\
\text { male }\end{array}$ & 10 & 30 & 3.5 & II versus III & 0.004 & 0.01 \\
\hline IV & $\begin{array}{l}\text { Exposed to } \\
\text { immature male }\end{array}$ & 10 & 40 & $5 \cdot 7$ & II versus IV & $0 \cdot 02$ & 0.05 \\
\hline V & $\begin{array}{l}\text { Anosmic } \\
\text { female exposed } \\
\text { to adult male }\end{array}$ & 20 & 35 & $2 \cdot 8$ & II versus $\mathrm{V}$ & $0 \cdot 01$ & 0.01 \\
\hline VI & $\begin{array}{l}\text { Sham anosmic } \\
\text { female exposed } \\
\text { to adult male }\end{array}$ & 10 & 90 & $11 \cdot 3$ & V versus VI & 0.02 & 0.02 \\
\hline
\end{tabular}

$\mathrm{N}=$ No. of female mice.

The need for an intact olfactory system in this phenomenon was shown by the use of anosmic mice. Animals were made anosmic when they were 20 days old by removal of the olfactory bulbs (Whitten, 1956b). Sham controls were prepared by simply exposing the olfactory bulbs but not removing them. When they were 24 days old, both types of animals were then exposed to intact adult males as described above. Five i.u. of HCG were injected $55 \mathrm{hr}$ later and animals were killed within $24 \mathrm{hr}$. Thirty-five per cent of the anosmic animals ovulated as compared to $90 \%$ of the sham controls (Groups V and VI, Table 2) demonstrating that anosmia in the female significantly blocks any facilitation of ovulation by the male $(P<0.02)$. As reported by many others, anosmia also significantly reduced the uterine weight.

The uteri of the control mice weighed $30.8 \mathrm{~g}$ while the uteri of the anosmic mice weighed $23.2 \mathrm{~g}$. The values for the anosmic animals were significantly decreased $(P<0.05)$.

The experiment with anosmic mice was also carried out with PMSG-induced ovulation and these data are shown in Table 1 (Groups V and VI). The dif- 
ference was not significant although more than twice as many of the sham anosmic mice ovulated. However, the mean number of ova recovered was 1.8 for the sham anosmic mice and 10.6 for the anosmic mice $(P<0.05)$.

The need for the presence of a pituitary gland in the induction of ovulation in the immature animal has been established (Quinn \& Zarrow, 1964). Whether or not the male's presence specifically stimulates FSH and LH release cannot be determined at this time. However, these findings agree with those of Bronson \& Desjardins (1969) and may be interpreted as indicating that exposure to the male induces both an LH release (Table 1) and an FsH release (Table 2). Recent reports now indicate that there is a surge of both LH and FSH near the time of ovulation (Galigaris, Astrada \& Taleisnik, 1967; Goldman \& Mahesh, 1968), but it is uncertain whether either of these hormones acts alone or whether both act in conjunction to trigger ovulation. It may be concluded that the adult male mouse provides a stimulus that promotes gonadotrophin secretion in the immature female and, as such, these findings present further evidence for a pheromonal effect on gonadotrophin release. They also indicate that a number of different effects may result from a single environmental stimulus acting through a pheromonal substance or substances.

Supported in part by Grant HD-04639 from NICHD, NIH. The PMSG and HCG were obtained through the courtesy of Dr L. B. Jewell, Ayerst Laboratories, New York.

\section{REFERENGES}

Bronson, F. H. \& Desjardins, C. (1969) Release of gonadotrophin in ovariectomized mice after exposure to males. F. Endocr. 44, 293.

BRUCE, H. M. (1959) An exteroceptive block of pregnancy in the mouse. Nature, Lond. 184, 105.

Caligaris, L., Astrada, J. J. \& Taleisnik, S. (1967) Pituitary fsh concentrations in the rat during the estrous cycle. Endocrinology, 81, 1261.

Eleftheriou, B. E., Bronson, F. H. \& Zarrow, M. X. (1962) Interaction of olfactory and other environmental stimuli on implantation in the deermouse. Science, $\mathcal{N} . Y .173,746$.

Goldman, B. D. \& MAHEsh, V. B. (1968) Fluctuations in pituitary FsH during the ovulatory cycle in the rat and a possible role of FSH in the induction of ovulation. Endocrinology, 83, 97.

LEE, S. vAN DER \& BOOT, L. M. (1955) Spontaneous pseudopregnancy in mice. Acta physiol. pharmac. néerl. 4, 442 .

PARKes, A. S. \& BRuge, H. M. (1961) Olfactory stimuli in mammalian reproduction. Science, N.r. 134, 1049.

QUinN, B. L. \& ZARROW, M. X. (1964) Inhibition of pregnant mare's serum-induced ovulation in the immature rat. Endocrinology, 74, 309.

Rowlands, I. W. (1942) Collection of eggs from the Fallopian tube of a rat. Nature, Lond. 150, 267.

VANDENBERGH, J. C. (1967) Effect of the presence of a male on the sexual maturation of female mice. Endocrinology, 81, 345.

Whitten, W. K. (1956a) Modification of the oestrous cycle of the mouse by external stimuli associated with the male. F. Endocr. 13, 399.

WhITTEN, W.K. (1956b) The effect of removal of the olfactory bulbs on the gonads of mice. F. Endocr. 14, 160.

Whrten, W. K. (1966) Pheromones and mammalian reproduction. In: Advances in Reproductive Physiology, vol. 1, pp. 155-177. Ed. A. McLaren. Academic Press, New York.

Wilson, E. D. \& Zarrow, M. X. (1962) Comparison of superovulation in the immature mouse and rat. F. Reprod. Fert. 3, 148.

Zarrow, M. X., Galdwell, A. L., Hafez, E. S. E. \& Pincus, G. (1958) Superovulation in the immature rat as a possible assay for LH and HCG. Endocrinology, 63, 748. 